\title{
NET POTASSIUM MOVEMENT BETWEEN RESTING MUSCLE AND PLASMA IN MAN IN THE BASAL STATE AND DURING THE NIGHT ${ }^{1}$
}

\author{
By REUBIN ANDRES, GORDON CADER, PETER GOLDMAN, AND \\ KENNETH L. ZIERLER

\begin{abstract}
(From the Departments of Environmental Medicine and Medicine, The Johns Hopkins University and Hospital, Baltimore, Md.)
\end{abstract}

(Submitted for publication July 5, 1956; accepted January 24, 1957)

Net movement of potassium between cells and extracellular fluid has been demonstrated in a variety of experimental conditions by direct analysis of muscle, by metabolic balance techniques, and by measurement of differences in potassium concentration in arterial blood and venous blood draining muscle. It has, for example, been demonstated that potassium leaves muscle during exercise, anoxia, potassium depletion, and under the influence of acidosis and of adrenal cortical hormones (1).

The present study demonstrates that there are, in addition, diurnal fluctuations in movement of potassium between skeletal muscle and extracellular fluid. Net movement of potassium between plasma and muscles of the forearm has been determined in human subjects by a technique which permits continuous monitoring of movement of potassium in relatively undisturbed muscle. Concentration of potassium is measured in arterial plasma and in venous plasma draining the deep forearm tissues. Plasma flow through the forearm is measured by the dye-dilution method (2). The product of flow, $F$, and the difference in arteriovenous concentration, $A-V$, defines $\dot{Q}$, the net quantity of potassium entering or leaving the forearm tissues per unit time.

\section{METHODS}

In vivo studies. Twenty-one male subjects ( 16 medical students and laboratory personnel and five convalescent ambulatory patients) were studied in the basal state between the hours of 10 A.M. and 1 P.M. Three medical

1 This work was performed under a contract between the Office of Naval Research, Department of the Navy, and The Johns Hopkins University (NR 113-241) and was further supported by grants-in-aid from the National Institutes of Health, Department of Health, Education, and Welfare (A-750), and the Muscular Dystrophy Associations of America, Inc. students, including two of the 21 subjects above, were also studied throughout the night and morning hours; i.e., from 10 P.M. to 11 A.M. Studies of carbohydrate metabolism in the first 13 of these subjects have been reported elsewhere $(3,4)$ and subject numbers in those papers correspond to those reported here. All subjects had their last meals between 6 and 7 P.M. and were at rest for at least one hour before blood was sampled. The arm was supported comfortably, and there was no overt activity of the forearm muscles during the period of study. Blood from the hand was eliminated by inflating to above systolic pressure a cuff about the wrist, applied five minutes prior to blood sampling. Blood was collected in heparinized syringes; metabolic inhibitors were not used. Consecutive pairs of arteriovenous samples were obtained at 12 to 60 minute intervals. Processing of blood was as expeditious as possible. Immediate centrifugation of the blood samples was carried out for ten minutes, plasma was transferred and re-centrifuged twice. A few visibly hemolyzed samples were discarded. Since 0.05 per cent hemolysis can be detected visually, the maximum increase in plasma potassium concentration resulting from undetected hemolysis was $0.02 \mathrm{mEq}$. per L. Handling of samples for potassium analysis was carried out at room temperature $\left(25^{\circ} \mathrm{C}\right)$ to minimize potassium and water shifts in erythrocytes (5) prior to their separation from plasma.

In vitro studies. A sample of antecubital venous blood was obtained anaerobically in a heparinized syringe. A drop of mercury was introduced and the sample was thoroughly mixed. Samples of blood were transferred anaerobically into duplicate syringes. Into one of these, 100 per cent $\mathrm{O}_{2}$ was introduced, and into the other a mixture of 5.0 to 6.4 per cent $\mathrm{CO}_{2}$ in $\mathrm{N}_{2}$. Gas volumes were varied to obtain the desired range of gas concentrations in the blood samples. Syringes were capped and the blood and gas phases were equilibrated at room temperature by rotation for ten minutes. Gases were expelled and blood was then handled as in the in vivo studies. Hematocrit determinations (Wintrobe) were performed in duplicate. Tubes were centrifuged for one hour at $1500 \mathrm{~g}$. and no correction was made for trapped plasma. In some studies, concentrations of $\mathrm{O}_{2}$ and $\mathrm{CO}_{2}$ were determined by the method of Van Slyke and Neill (6).

Potassium analysis. Duplicate or triplicate dilutions of plasma were made and concentrations were measured 
with the Beckman Model DU flame photometer. The precision of the analysis is as follows: the standard error of the estimate of the mean concentration from duplicate analyses of a single blood sample is $0.04 \mathrm{mEq}$. per L. The standard error of the estimate of a single arteriovenous difference then is $0.06 \mathrm{mEq}$. per $\mathrm{L}$. for samples diluted in duplicate. On the average, three pairs of arterial and venous samples were obtained from each subject in the basal state and only the mean of these multiple samples is reported. In general, the standard error (analytical) of the estimate of mean A-V difference to be presented for each subject in Table $I$ is 0.03 mEq. per $\mathrm{L}$. For the entire series of 21 subjects, the standard error of the estimated overall mean $\mathrm{A}-\mathrm{V}$ difference is less than $0.01 \mathrm{mEq}$. per $\mathrm{L}$.

\section{RESULTS}

\section{Potassium movement in the basal state}

Sixty-five individual A-V differences were obtained in 21 subjects studied 16 to 19 hours post-

TABLE I

Movement of potassium in the basal state *

\begin{tabular}{|c|c|c|c|c|}
\hline Subject & $\begin{array}{l}\text { Number } \\
\text { of pairs }\end{array}$ & $\underset{m E q . / L}{\mathbf{A R}}$ & $\underset{m E q . / L .}{(A-V) \mathbf{K}}$ & 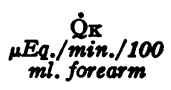 \\
\hline $\begin{array}{l}1 \\
2 \\
3 \\
4 \\
5 \\
6 \\
7 \\
8 \\
9 \\
10 \\
11 \\
12(\mathrm{C}) \\
13(\mathrm{~K}) \\
14 \\
15 \\
16 \\
17 \\
18 \\
19 \\
20 \\
21\end{array}$ & $\begin{array}{l}6 \\
6 \\
6 \\
3 \\
3 \\
3 \\
2 \\
1 \\
1 \\
1 \\
3 \\
2 \\
3 \\
3 \\
3 \\
3 \\
3 \\
4 \\
3 \\
3 \\
3\end{array}$ & $\begin{array}{l}4.36 \\
4.19 \\
4.07 \\
3.90 \\
4.28 \\
3.90 \\
3.77 \\
3.82 \\
3.72 \\
4.49 \\
4.51 \\
3.91 \\
4.04 \\
4.14 \\
3.89 \\
4.03 \\
3.98 \\
3.94 \\
3.65 \\
4.04 \\
3.95\end{array}$ & $\begin{array}{l}-0.31 \\
-0.46 \\
-0.15 \\
-0.23 \\
-0.01 \\
-0.23 \\
-0.16 \\
-0.14 \\
-0.03 \\
-0.38 \\
-0.10 \\
-0.07 \\
-0.09 \\
-0.96 \\
-0.44 \\
+0.01 \\
-0.64 \\
-0.28 \\
+0.23 \\
-0.16 \\
-0.19\end{array}$ & $\begin{array}{l}-0.88 \\
-0.50 \\
-0.37 \\
-0.17 \\
-0.10 \\
-0.83 \\
-0.18 \\
-0.17 \\
-2.19 \\
-1.86 \\
+0.11 \\
-2.69 \\
+0.54 \\
-0.21 \\
-0.43\end{array}$ \\
\hline $\begin{array}{l}\text { Mean } \\
\text { S.D. } \\
\text { S.E.M. }\end{array}$ & 3 & $\begin{array}{l}4.03 \\
0.233 \\
0.051\end{array}$ & $\begin{array}{r}-0.229 \\
0.253 \\
0.055\end{array}$ & $\begin{array}{r}-0.662 \\
0.902 \\
0.233\end{array}$ \\
\hline
\end{tabular}

* $A_{K}$ is the concentration of potassium in arterial plasma. $(A-V)_{K}$ is the arteriovenous difference in plasma concentration of potassium. $\dot{Q}_{K}$ is the calculated net potassium movement; the minus sign indicates that net movement was from muscle to plasma. Values in each column are the means for each subject. Plasma flow was not successfully measured in six subjects (see Reference 2), and $\dot{Q}_{\mathrm{K}}$ for each of these was therefore not calculated. S.D. is the standard deviation and S.E.M. is the standard error of the mean.
TABLE II

Movement of potassium during the night *

\begin{tabular}{|c|c|c|c|c|}
\hline Sample & Time & $\underset{m E q .}{\mathrm{Ax}} / L$. & $\underset{m E q . / L}{(\mathrm{~A}-\mathrm{V}) \mathrm{k}}$ & $\begin{array}{c}\dot{Q}_{\mathrm{K}} \\
\mu E q . / \text { min. } \\
100 \mathrm{ml} . \\
\text { forearm }\end{array}$ \\
\hline \multicolumn{5}{|l|}{ Subject C: } \\
\hline $\begin{array}{l}1 \\
2 \\
3 \\
4 \\
5 \\
6 \\
7 \\
8 \\
9\end{array}$ & $\begin{array}{r}\text { 11:43 P.M. } \\
\text { 1:00 A.M. } \\
\text { 2:00 } \\
\text { 3:00 } \\
\text { 5:00 } \\
\text { 7:00 } \\
\text { 9:00 } \\
10: 00 \\
11: 00\end{array}$ & $\begin{array}{l}3.91 \\
3.91 \\
4.17 \\
3.86 \\
3.81 \\
3.88 \\
3.84 \\
3.90 \\
3.92\end{array}$ & $\begin{array}{l}-0.32 \\
+0.03 \\
+0.35 \\
-0.09 \\
-0.09 \\
-0.04 \\
-0.17 \\
-0.03 \\
-0.11\end{array}$ & $\begin{array}{l}-0.89 \\
+0.08 \\
+1.12 \\
-0.25 \\
-0.40 \\
-0.07 \\
-0.42 \\
-0.13 \\
-0.23\end{array}$ \\
\hline \multicolumn{5}{|l|}{ Subject K: } \\
\hline $\begin{array}{r}1 \\
2 \\
3 \\
4 \\
5 \\
6 \\
7 \\
8 \\
9 \\
10\end{array}$ & $\begin{array}{l}\text { 11:53 P.M. } \\
1: 00 \text { A.M. } \\
2: 00 \\
3: 30 \\
5: 00 \\
6: 30 \\
8: 00 \\
10: 13 \\
10: 35 \\
11: 02\end{array}$ & $\begin{array}{l}3.93 \\
3.95 \\
3.94 \\
3.92 \\
3.89 \\
4.16 \\
4.17 \\
4.03 \\
4.00 \\
4.10\end{array}$ & $\begin{array}{l}-0.12 \\
+0.01 \\
-0.02 \\
-0.11 \\
-0.06 \\
+0.02 \\
-0.09 \\
-0.09 \\
-0.09\end{array}$ & $\begin{array}{l}-0.23 \\
+0.02 \\
-0.04 \\
-0.17 \\
-0.07 \\
+0.04 \\
-0.18 \\
-0.17 \\
-0.17\end{array}$ \\
\hline \multicolumn{5}{|l|}{ Subject N: } \\
\hline $\begin{array}{l}1 \\
2 \\
3 \\
4 \\
5 \\
6 \\
7 \\
8\end{array}$ & $\begin{array}{l}\text { 10:00 P.M. } \\
\text { 11:30 } \\
\text { 1:00 A.M. } \\
\text { 3:00 } \\
\text { 5:00 } \\
\text { 7:00 } \\
\text { 8:00 } \\
\text { 9:00 }\end{array}$ & $\begin{array}{l}3.86 \\
3.84 \\
3.76 \\
3.82 \\
3.90 \\
3.86 \\
3.82 \\
3.90\end{array}$ & $\begin{array}{l}-0.31 \\
+0.10 \\
+0.04 \\
+0.05 \\
+0.04 \\
+0.02 \\
+0.01 \\
+0.12\end{array}$ & \\
\hline
\end{tabular}

* See legend to Table I for explanation of symbols.

prandially. In only seven samples was the arterial concentration higher than the venous. The mean $\mathrm{A}-\mathrm{V}$ difference in 19 of the 21 subjects was negative, the grand mean being $-0.23 \mathrm{mEq}$. per $\mathrm{L}$. (Table I). The net loss of potassium from tissue to blood in 15 subjects averaged $0.66 \mu \mathrm{Eq}$. per min. per $100 \mathrm{ml}$. forearm tissue. $\dot{Q}$ can be calculated in terms of forearm muscle by multiplying 0.66 by $4 / 3$ (see Reference 3 ), giving a mean loss of 0.88 $\mu \mathrm{Eq}$. per min. per $100 \mathrm{~g}$. forearm muscle.

\section{Potassium movement during the night}

Results on the three subjects are given in Table II and Figure 1. Measurement of plasma flow was made in subjects $C$ and $K$ but was unsuccessful in subject $N(2)$. It appears that between the hours of 1 and 8 A.M. there is no net movement of potassium, the overall mean and median $A-V$ difference during this time being $+0.01 \mathrm{mEq}$. per 


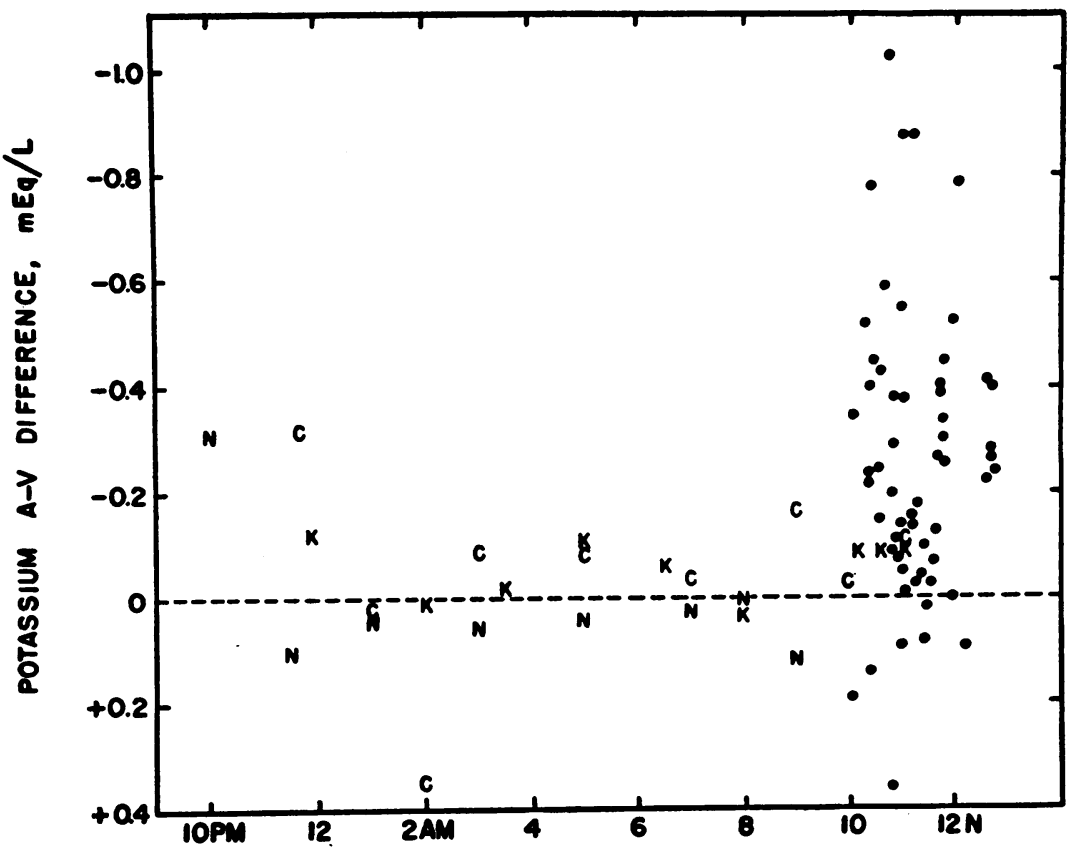

Fig. 1. Tma Course of Arteriovenous Difference in Plasma Potassium CONCENTRATION

$\mathrm{C}, \mathrm{K}$ and $\mathrm{N}$ refer to subjects followed during the night. Black dots represent all A-V differences obtained in nineteen additional subjects studied only between 10 A.M. and 1 P.M.

L., and only one of the $15 \mathrm{~A}-\mathrm{V}$ differences lies outside the range expected from analytical error alone. These results are in contrast to the larger series of results obtained during the late morning hours. In the few observations made prior to 1 A.M. there seems also to be real loss of potassium from the forearm.

In summary, the general trend is one of potassium loss from muscle prior to 1 A.M., little or no net movement during most of the night, then increasing potassium loss in the later morning hours.

Evidence that the observed $A-V$ differences in potassium concentration represent net movement of potassium between forearm muscle and blood

1) Transiently negative $A-V$ differences might be observed if the concentration of potassium in arterial plasma were falling during the period of study with consequent net diffusion of potassium from interstitial fluid into capillaries. However, only very minor fluctuations in concentration of arterial potassium occurred and there was no consistent directional trend. On the average the concentration decreased $0.004 \mathrm{mEq}$. per $\mathrm{L}$. \pm 0.018 (S.E.M.) in consecutive samples.
2) Since potassium escapes from anoxic muscle (7), it was necessary to demonstrate that no leak of blood from ischemic hand tissues distal to the pressure cuff at the wrist occurred. Evidence that there was no such leak has been previously presented (3).

3) The chief source of the potassium added to venous blood might be forearm tissues other than muscle, that is, skin, tendon or bone. The placement of the venous catheter deeply into the forearm muscle mass minimizes possible contribution from skin. Of the potassium in the remaining tissues, there is probably 20 times as much in muscle as there is in bone and tendon combined, if concentrations in human tissues are similar to those in the rat (8). Nevertheless, a portion of the observed potassium loss may be from tissues other than muscle.

4) In vitro studies of net potassium and water movement between blood cells and plasma were made to examine the possibility of significant shift of potassium, of water, or of both, either (a) in the arm as arterial blood becomes venous, or (b) in shed blood during the several minutes which elapse before cells are separated from plasma. 
In case (a), these shifts to a new equilibrium state might be considered as accompaniments of the classical "chloride shift" (9). That is, either movement of water into erythrocytes or potassium out of erythrocytes, or both, might lead to a higher venous than arterial plasma concentration of potassium.

In case (b) it is conceivable that, as shed arterial and venous blood cool from $38^{\circ} \mathrm{C}$ toward room temperature of $25^{\circ}$, net potassium uptake by arterial erythrocytes might occur at a faster rate than by venous erythrocytes; or, net water uptake by arterial erythrocytes might occur at a slower rate than by venous erythrocytes.

These possible artefacts could be avoided by determining potassium concentrations in whole blood rather than in plasma. Concentrations in whole blood are so high, however, that a small analytical error percentagewise would become intolerably large in detecting small net potassium shifts.

In both cases (a) and (b), in order for water shifts to account for the observed differences in potassium concentration, the volume of packed cells in venous blood would have to exceed that in arterial blood by $2.3 \mathrm{ml}$. per $100 \mathrm{ml}$. blood on the average. In 35 pairs of arterial and venous blood samples obtained in 12 of the subjects, there was no significant $\mathrm{A}-\mathrm{V}$ difference, the mean being only $+0.2 \mathrm{ml}$. per $100 \mathrm{ml}$. \pm 0.2 (S.E.M.).
Water shifts, then, are not responsible for the observed potassium differences. However, since the possibility of a potassium shift in erythrocytes remained, in vitro studies were devised so that the changes in gas content occurring in blood flowing through the arm would be reversed. The sample of venous blood equilibrated with oxygen becomes "arterialized": $\mathrm{O}_{2}$ is gained and $\mathrm{CO}_{2}$ is lost. The paired sample of venous blood which is exposed to the $\mathrm{CO}_{2}-\mathrm{N}_{2}$ mixture serves as a control: the blood is subjected to the same manipulative procedures but remains venous.

In eleven in vitro experiments (Table III) there is a significantly greater concentration of potassium in the "venous" than in the "arterial" sample, but the mean difference, $0.03 \mathrm{mEq}$. per L., is only $1 / 7$ the mean difference in the experiment upon the forearm. The difference between in vivo and in vitro $\mathrm{A}-\mathrm{V}$ differences is highly significant ( $p<0.01)$. However, unlike the forearm experiments, a significant difference in "arterial" and "venous" hematocrits occurred in the in vitro studies. In only one of ten pairs was this water shift large enough to account completely for the observed difference in potassium concentration (Table III, columns headed "\% Water shift" and "\% Change in potassium"). There therefore appears to be not only a water shift but also a direct

TABLE III

Movement of potassium between red cells and plasma with changes in $\mathrm{O}_{2}$ and $\mathrm{CO}_{2}$ contents *

\begin{tabular}{|c|c|c|c|c|c|c|c|}
\hline Expt. & Ar & $(A-V)_{\mathbf{r}}$ & $(A-V)_{2}$ & $(A-V) \infty_{2}$ & $(\mathrm{~A}-\mathrm{V})_{\text {Hot }}$ & $\begin{array}{c}\% \text { Water } \\
\text { shift }\end{array}$ & $\begin{array}{l}\text { \% Change in } \\
\text { potassium }\end{array}$ \\
\hline $\begin{array}{l}\text { A } \\
\text { B } \\
\text { C } \\
\text { D } \\
\text { E } \\
\text { F } \\
\mathbf{G} \\
\text { H } \\
\text { I } \\
\text { J } \\
\mathbf{K}\end{array}$ & $\begin{array}{l}3.67 \\
3.81 \\
3.95 \\
3.68 \\
3.74 \\
3.73 \\
3.91 \\
4.19 \\
3.61 \\
4.05 \\
4.01\end{array}$ & $\begin{array}{c}-0.01 \\
-0.13 \\
-0.01 \\
+0.01 \\
-0.03 \\
-0.05 \\
0 \\
-0.04 \\
-0.04 \\
-0.01 \\
-0.07\end{array}$ & $\begin{array}{r}9.4 \\
13.9 \\
15.4 \\
13.4\end{array}$ & $\begin{array}{l}-1.6 \\
-1.6 \\
-3.4 \\
-2.3\end{array}$ & $\begin{array}{c}-0.4 \\
-1.4 \\
-0.1 \\
-0.2 \\
-0.3 \\
+0.1 \\
0 \\
-0.2 \\
0 \\
-0.7\end{array}$ & $\begin{array}{c}-0.7 \\
-2.6 \\
-0.2 \\
-0.4 \\
-0.6 \\
+0.3 \\
0 \\
-0.3 \\
0 \\
-1.2\end{array}$ & $\begin{array}{c}-0.2 \\
-3.4 \\
-0.4 \\
+0.3 \\
-0.7 \\
-1.4 \\
0 \\
-1.0 \\
-1.3 \\
0 \\
-1.7\end{array}$ \\
\hline $\begin{array}{l}\text { Mean } \\
\text { S.E.M. }\end{array}$ & 3.850 & $\begin{array}{c}-0.034 \\
0.0120\end{array}$ & 12.4 & -3.5 & $\begin{array}{c}-0.31 \\
0.140\end{array}$ & $\begin{array}{r}-0.57 \\
0.260\end{array}$ & $\begin{array}{r}-0.96 t \\
0.338\end{array}$ \\
\hline
\end{tabular}

* A refers to the concentration in the "arterialized" sample; V, to that in the venous sample; A-V, to the arteriovenous difference. Potassium concentration is in $\mathrm{mEq}$. per $\mathrm{L}$. plasma; gas concentrations are in ml. per $100 \mathrm{ml}$. blood. Hematocrit, Hct, is in ml. packed cells per $100 \mathrm{ml}$. blood. $\%$ Water shift $=\frac{(\mathrm{V}-\mathrm{A})_{\text {plasmaorit }}}{\mathrm{A}_{\text {plamacrit }}} 100$. $\% \mathrm{Change}$ in potassium $=\frac{(\mathrm{A}-\mathrm{V})_{\mathbf{K}}}{\mathrm{A}_{\mathbf{K}}} 100$.

$\dagger$ Experiment $A$ omitted from calculation of the mean since per cent water shift was not measured in this subject. 
potassium shift in the in vitro studies, both quantitatively very small.

Venous plasma concentrations, as measured in the forearm experiments, might be corrected for possible movements of water and potassium between erythrocytes and plasma by subtracting 0.03 $\mathrm{mEq}$. per L. However, in view of the fact that a water shift has been shown not to occur in the in vivo experiments, there is some justification for not correcting for that portion (60 per cent) of the in vitro potassium $\mathrm{A}-\mathrm{V}$ difference which can be attributed to a water shift. The correction then would be only $0.01 \mathrm{mEq}$. per $\mathrm{L}$., a value so small that it was deemed inadvisable to carry out any correction.

From these in vitro experiments it cannot be stated whether these erythrocyte-plasma exchanges occurred during passage of blood through the arm or during the handling of the shed blood.

\section{DISCUSSION}

These studies demonstrate that, in addition to factors described previously as influencing transcellular movement of potassium, there is a net loss of potassium from skeletal muscle to extra- cellular fluid in the late morning hours. During the night there appears to be no net movement, so that in the 12 hours of the 24 included in this study there is an overall loss of potassium from muscle. Restitution has not been demonstrated; it is likely that this occurs with potassium ingestion in food.

The morning loss of potassium from muscle averages $0.88 \mu \mathrm{Eq}$. per min. per $100 \mathrm{~g}$. muscle, or 0.5 per cent of the intracellular potassium per hour. If extrapolation from forearm to total body muscle is valid, an increase in the extracellular concentration of potassium of $1.0 \mathrm{mEq}$. per $\mathrm{L}$. would be expected in one hour. Yet, arterial concentration remains constant. It is clear that potassium must leave the extracellular fluid at about the rate at which it is added to extracellular fluid from muscle. Studies by others $(10,11)$ of the diurnal variation of urinary excretion of potassium show a striking similarity to the pattern of net potassium movement from muscle. That is, excretion falls to minimal levels during the night, and rises sharply to a maximum output at 10 or 11 A.M. (compare Figure 1). It would appear that urinary loss is the likely fate of the bulk of the potassium added to extracellular fluid from muscle;

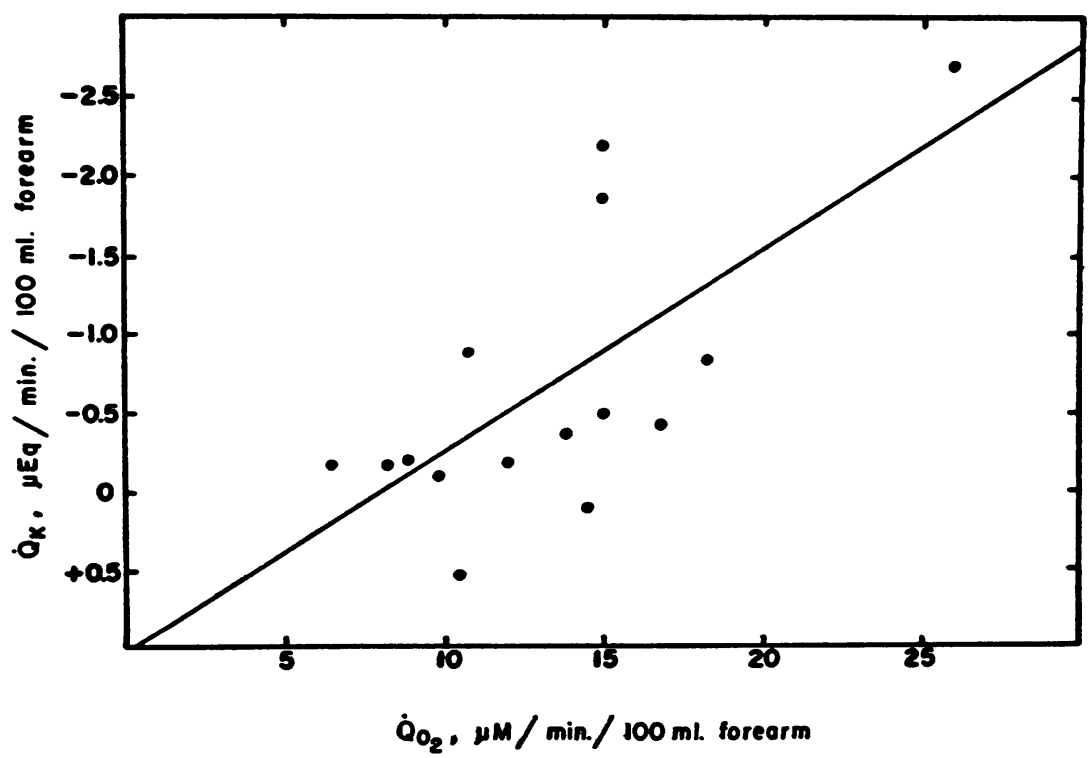

Fig. 2. Correination Between Oxygen Consumption of Forearm Tissues and Movement of Potassium Between Forearm Tissues and Blood

Each dot represents the mean value for each subject studied in the basal state. Line of regression calculated by "least squares" method. Probability of correlation by chance, $<0.01$. 


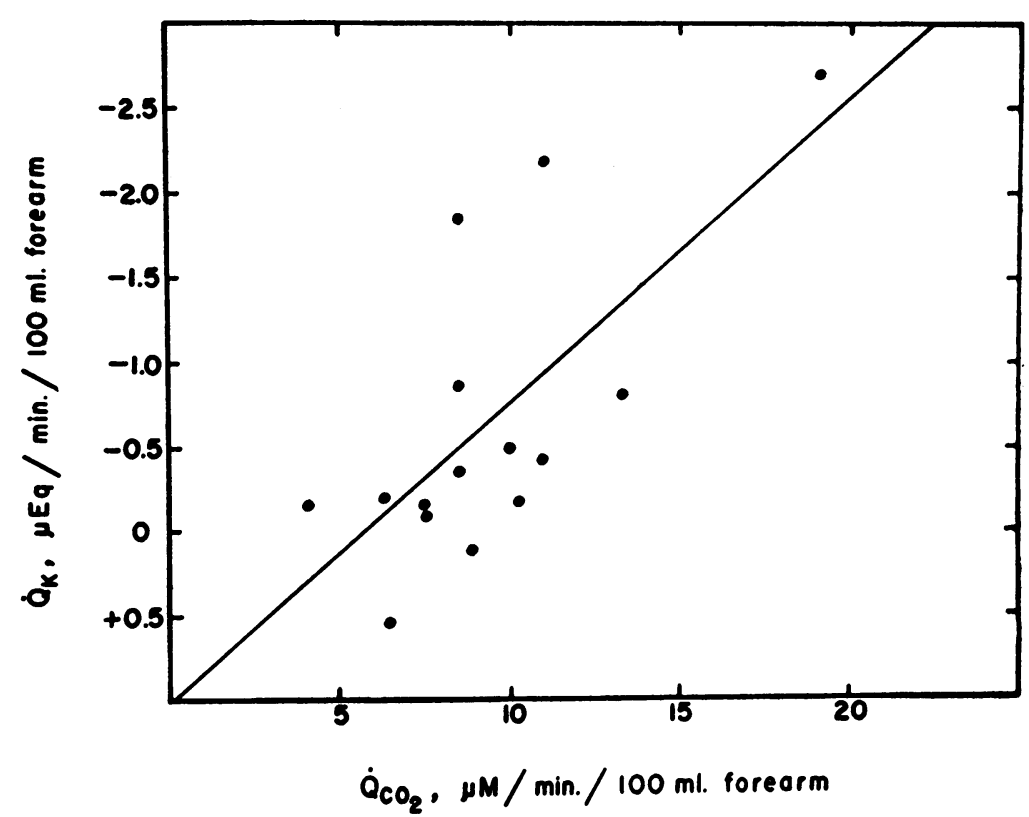

Fig. 3. Correlation Between $\mathrm{CO}_{2}$ Production by Forearm Tissues and Monement of Potassium Between Forearm Tissues and Blood

Each dot represents the mean value for each subject studied in the basal state. Line of regression calculated by "least squares" method. Probability of correlation by chance, $<0.01$.

some potassium may, however, enter the cells of other organs, for example, liver.

The similarity of the time course of movement of potassium out of muscle and into urine suggests that the two are causally related. It is not known which of these processes may be primary, or indeed whether both are secondary to another common mechanism. The association of adrenocortical activity with electrolyte metabolism and the striking diurnal variation of adrenocortical activity (11) suggest that this may be the common trigger to muscle and kidney. Others (10) have suggested that the diurnal rhythm of potassium excretion is caused by cyclic changes in renal tubular metabolism with consequent changes in intracellular $\mathrm{pH}$. These two suggestions are not mutually exclusive.

Carbohydrate metabolism of the forearm was studied in these subjects by measuring the net movement between forearm tissues and blood of glucose, lactate, oxygen and carbon dioxide simultaneously with potassium on the same samples of blood. Data on carbohydrate metabolism in the first 13 of these subjects have been reported previously $(3,4)$. The relation between movement of potassium and of these metabolites in the basal state was examined.

Oxygen. Since anoxia of muscle leads to loss of potassium, it might have been expected that subjects with the lowest $\mathrm{O}_{2}$ consumption would have the greatest loss of potassium from muscle. However, the reverse was true (Figure 2).

Lactate. Lactate was produced by the resting forearm (mean $=0.44 \mu \mathrm{M}$ per min. per $100 \mathrm{ml}$. forearm \pm 0.11 S.E.M.). It is possible that there are small areas of muscle which are intermittently ischemic, perhaps as a result of rhythmic vasomotor activity, which accounts for this anaerobic metabolism. If so, correlation between lactate production by muscle and potassium loss from muscle would be expected. There was, however, no correlation.

Glucose. Glucose uptake by forearm tissue was small, averaging only $0.50 \pm 0.17 \mu \mathrm{M}$ per min. per $100 \mathrm{ml}$. forearm, and no correlation with potassium movement was present. The movement of potassium into cells along with glucose is generally attributed either to a) an increase in concentration within the cell of the potassium salt of the hexose phosphates or b) an increase of intracellular 
fluid (and, therefore, of potassium) with glycogen deposition. With such a low uptake of glucose it would not be expected that either of these two processes occurred; in fact, breakdown of previously deposited glycogen would seem more likely and this might lead to a loss of associated potassium from muscle. Available data in the literature do not permit, however, an acceptable estimate of the quantity of glycogen breakdown required to account for the observed potassium movement. The mean R.Q. of the forearm in these subjects $(0.74 \pm 0.02)$ suggests that glucose oxidation, and therefore glycogenolysis, must be minor and there is other evidence suggesting that little breakdown of glycogen in muscle is to be expected (3). There was also no correlation between movement of potassium and forearm R.Q.

Carbon dioxide. It has been demonstrated that acute acidosis, both respiratory and metabolic, leads to loss of potassium from muscle $(12,13)$. In the forearm experiments there was a highly significant correlation between $\mathrm{CO}_{2}$ production by the forearm and net potassium movement (Figure 3). Greater $\mathrm{CO}_{2}$ production does not, however, necessarily imply increased intracellular acidosis, since intracellular $\mathrm{CO}_{2}$ concentration is a function not only of the rate of $\mathrm{CO}_{2}$ production but also of the rate of $\mathrm{CO}_{2}$ removal. $\mathrm{CO}_{2}$ concentration in venous blood or the $\mathrm{A}-\mathrm{V}$ difference in $\mathrm{CO}_{2}$ concentration might then be better indices of tissue $\mathrm{pH}$; neither of these correlated with the net movement of potassium. Since neither $\mathrm{pH}$ nor $\mathrm{pCO}_{2}$ was measured, it is not possible from these experiments to be certain what role tissue $\mathrm{pH}$ might play.

In the three subjects studied during the night there was no correlation between movement of potassium and of any other metabolite.

\section{SUMMARY}

There is net movement of potassium out of resting forearm muscle into plasma in the late morning hours in fasted subjects. From 1 A.M. to 10 A.M. no net movement occurs. From 10 A.M. to 1 P.M. the mean A-V difference in 21 subjects was $-0.23 \mathrm{mEq}$. per $\mathrm{L}$. The net loss in 15 subjects averaged $0.88 \mu \mathrm{Eq}$. per min. per 100 g. muscle, or about 0.5 per cent per hour of intracellular potassium.

\section{REFERENCES}

1. Danowski, T. S., and Elkinton, J. R., Exchanges of potassium related to organs and systems. Pharmacol. Rev., 1951, 3, 42.

2. Andres, R., Zierler, K. L., Anderson, H. M., Stainsby, W. N., Cader, G., Ghrayyib, A. S., and Lilienthal, J. L., Jr., Measurement of blood flow and volume in the forearm of man; with notes on the theory of indicator-dilution and on production of turbulence, hemolysis, and vasodilatation by intra-vascular injection. J. Clin. Invest., 1954, 33, 482.

3. Andres, R., Cader, G., and Zierler, K. L., The quantitatively minor role of carbohydrate in oxidative metabolism by skeletal muscle in intact man in the basal state. Measurements of oxygen and glucose uptake and carbon dioxide and lactate production in the forearm. J. Clin. Invest., 1956, 35, 671.

4. Zierler, K. L., and Andres, R., Carbohydrate metabolism in intact skeletal muscle in man during the night. J. Clin. Invest., 1956, 35, 991.

5. Raker, J. W., Taylor, I. M., Weller, J. M., and Hastings, A. B., Rate of potassium exchange of the human erythrocyte. J. Gen. Physiol., 1950, 33, 691.

6. Van Slyke, D. D., and Neill, J. M., The determination of gases in blood and other solutions by vacuum extraction and manometric measurement. I. J. Biol. Chem., 1924, 61, 523.

7. Fuhrman, F. A., and Crismon, J. M., Muscle electrolytes in rats following ischemia produced by tourniquets. Am. J. Physiol., 1951, 167, 289.

8. Levitt, M. F., Turner, L. B., Sweet, A. Y., and Pandiri, D., The response of bone, connective tissue, and muscle to acute acidosis. J. Clin. Invest., 1956, 35, 98.

9. Peters, J. P., and Van Slyke, D. D., Quantitative Clinical Chemistry. Vol. I., Baltimore, Williams \& Wilkins Co., 1932.

10. Stanbury, S. W., and Thomson, A. E., Diurnal variations in electrolyte excretion. Clin. Sc., 1951, 10, 267.

11. Doe, R. P., Flink, E. B., and Goodsell, M. G., Relationship of diurnal variation in 17-hydroxycorticosteroid levels in blood and urine to eosinophils and electrolyte excretion. J. Clin. Endocrinol. \& Metab., 1956, 16, 196.

12. Scribner, B. H., Fremont-Smith, K., and Burnell, J. M., The effect of acute respiratory acidosis on the internal equilibrium of potassium. J. Clin. Invest., 1955, 34, 1276.

13. Fenn, W. O., and Cobb, D. M., The potassium equilibrium in muscle. J. Gen. Physiol., 1934, 17, 629. 